\title{
The Effectiveness of Blended Learning for New Generation Learning Materials to Train Science Process Skills
}

\author{
A. A. Ketut Budiastra ${ }^{1}$, Hartinawati Hartinawati ${ }^{1}$, Ichwan Ichwan ${ }^{1}$, Nia Erlina ${ }^{2}$ \\ ${ }^{1}$ Universitas Terbuka, Faculty of Teacher Training and Education, Jakarta, Indonesia \\ ${ }^{2}$ Universitas Pendidikan Ganesha, Faculty of Mathematics and Natural Science, Singaraja, Indonesia
}

\begin{abstract}
The development of the ICT has influenced various fields of life, including the development of teaching materials for undergraduate students of elementary school teacher programs of a distance university. This research aims to describe the effectiveness of blended learning of the new generation of science learning materials for science process skills. This research implements a quasi-experimental type of research. Respondents in this research were 56 students in the UT Regional Office area of Jember East of Java Indonesia. The results showed the students' mastery of science process skills and learning outcomes in natural science learning materials in both moderate and high categories. Student responses showed great interest in the science content, the teaching materials, and the learning atmosphere. The constraints faced in blended learning are the internet network to support the ICT-based tutorials and the challenge to change the habit of using printed science teaching materials during teaching within blended learning.
\end{abstract}

Keywords - blended learning, science teaching, science process skills, distance learning

DOI: $10.18421 /$ SAR42-04

https://doi.org/10.18421/SAR42-04

Corresponding author: A. A. Ketut Budiastra, Universitas Terbuka, Faculty of Teacher Training and Education, Jakarta, Indonesia

Email: budiastra@ecampus.ut.ac.id

Received: 23 March 2021.

Revised: 14 June 2021.

Accepted: 20 June 2021.

Published: 27 June 2021.

(C) 2021 A. A. Ketut Budiastra et al; published by UIKTEN. This work is licensed under the CC BY-NC 4.0 licence.

The article is published with Open Access at www.sarjournal.com

\section{Introduction}

The natural sciences generally cover three basic science fields, namely physics, biology, and chemistry. Science learning is essentially a product, process, and application [1]. As a product, science is a collection of knowledge and a set of concepts and concept charts. As a process, science is used to research objects, discover and develop scientific products. As an application, science theory will give birth to technologies that can provide convenience for life [2]. The learning model is a pattern or plan that has been planned in such a way and is used to arrange the curriculum, organize the subject matter, and give instructions to the instructors in the class [3]. The learning model is a whole series of presentations of teaching material that covers all aspects before, during, and after learning, by the teacher and all related facilities that are used directly or indirectly in the learning process. The science learning model illustrates how science learning is carried out. Nowadays, various learning models have been developed by experts [4]. Some of the learning models are specifically designed, such as the blended learning of the new generation of science learning materials for science process skills. Blended learning is a learning facility that combines a variety of ways of delivery, teaching models, and learning styles, introducing various choices of media dialogue between the facilitator and the people who are taught. Blended learning is also a combination of direct teaching (face to face) and online teaching, but more than that as an element of social interaction [5].

Science learning in elementary schools is intended to provide opportunities for students to naturally develop curiosity, develop the ability to ask and seek answers to natural phenomena based on evidence, and develop scientific thinking. An essential aspect that teachers must consider in implementing science learning in elementary schools is to involve students in learning to develop their thinking abilities actively. Science learning begins by paying attention to students' initial conceptions/knowledge that is 
relevant to what will be discovered [6]. Learning activities are designed through various real activities with nature. Practical experience activities with life can be done in the classroom or laboratory with teaching aids or directly in the open. Through actual activities with life, students can develop process skills and scientific attitudes such as observing, trying, summarizing the results of actions, and communicating the conclusions of their activities. Science learning activities are also designed as much as possible to allow students to ask questions. By asking, children will practice expressing ideas and responses to the problems they face so they can develop science knowledge [7].

Science Process Skills is an approach that emphasizes facts and conceptual methods used in science learning that is based on the steps of activities in testing something that is usually done by scientists when building or proving a theory. The process can be defined as a complex set of skills that scientists use in conducting scientific investigations. The scientific process or method is a great concept that can be broken down into several components that must be mastered if the person wishes to carry out research and development in his field [8]. Science is taken from the Latin word Scientia, which means knowledge. Scientists develop theories, among others, through process skills with a scientific approach. The science process skills that must be developed include (1) observation, (2) classification, (3) interpretation, (4) prediction, (5) hypothesis, (6) controlling variables, (7) planning and carrying out research, (8) inference, (9) application, and (10) communication [9]. The necessary skills of the scientific process for the elementary school level include observing, classifying, measuring, communicating, predicting, and inferring [10]. Children's process skills are observing, trying to understand what is seen, using new knowledge to predict what will happen, and testing the truth of the prediction [11]. Undergraduate students of elementary school teacher programs need to have science process skills. Students who want to improve their science process skills should be accustomed to learn more by themselves so they can discover concepts, scientific principles, and develop creativity in solving scientific problems whose implementation is guided by an intensive tutor.

The $21^{\text {st }}$-century competencies that need to be achieved by students are related to high-level cognitive integrated technology. The development of information and communication technology can be used as a learning medium. One result of the development of information and communication technology is the Internet [12]. The rapid growth of information and communication technology requires all parties to develop themselves and adapt and go with the flow by utilizing technology in all activities [13]. Utilization of Information and Communication Technology (ICT) in learning initially tends to be a piece of information or a portion of information whose structure has not been carefully studied following the curriculum [14]. The utilization of the ICT by education practitioners is also without an adequate pedagogical basis, so its effectiveness varies greatly. Several research findings report that the use of ICT has produced inconsistent results [15]. This contradictory result is partly due to the low strength of the ICT-based learning resources used and the inaccurate integration strategy in learning.

Blended learning is one of the learning modes that has attracted the attention of many interested parties in the field of education in the 21 st century [43, 44, 45]. Blended learning is learning that combines faceto-face learning with e-learning [16]. It is a new concept in learning where the delivery of material can be done in class and online [17]. A good combination of face-to-face teaching is the one where teachers and students meet face to face and through online media that can be accessed at any time. Therefore, it is more flexible in terms of time, environment, and media. There are several keys to implementing learning using blended learning, namely live events, self-learning, collaboration, assessment, performance support materials [18]. Direct learning is carried out by students together as a face-to-face situation (instructor-led instruction) which is carried out at the same time and in-class condition. This type of learning is also carried out by students at the same time with different classes (virtual classes). Direct learning patterns are still the main guide in certain learning conditions. Thus, certain design patterns need to be applied to direct learning in accordance with the goals and needs [19]. This pattern can also combine the theories of behaviourism, cognitivism, and constructivism that support learning that involves thinking activities and student skills. Self-paced learning is a combination of independent learning that allows participants to join in learning anytime and anywhere. The teaching uses a kind of concept or learning materials for independent learning. The design is text-based or multimedia-based (interactive-based video, animation media, simulation, images, audio, or a design combination). These learning materials, in the current context, can be delivered online (via the web or through mobile devices in the form of streaming audio, video, and e-books) or offline (on $\mathrm{CD}$, and in print) [20]. In this research, the development of a new generation of science learning materials for the elementary school teacher programs refers to blended learning [21], [22].

Universitas Terbuka (UT) applies a distance and open learning system. The term distance means that 
learning is not done face to face directly. Instead, it uses the media, both print media (modules) and nonprint media (audio/video, computer/internet, radio broadcasts, and television). UT students are expected to be ready and able to carry out learning independently [23]. Based on the analysis of needs and relevant theoretical support, the researcher conducted an innovation, namely the "Blended Learning of New Generation Science Learning Materials for Science Process Skills." Teaching materials developed are integrated with the ICT so that students who are familiar with the use of the internet will like this learning. Students who are familiar with printed teaching materials will enjoy this learning because blended learning encourages students to be good at using computers and the internet, and the material presented. Blended learning is a combination of traditional classroom learning with technology-based learning [24]. It provides the best opportunity for learning from class transition to learning. Blended learning involves class (or face-toface) and online learning [25]. This method is very effective in increasing the efficiency of the implementation of the independence of UT students and allows increased discussion or review of information outside the classroom. Thus, blended learning is an appropriate integration strategy in learning. In particular, distance learning systems need media support and online learning resources.

\section{Methodology}

This research is a quasi-experimental type of research. This type of quasi-experimental approach is more helpful for researchers to see the causal relationship of various existing situations. This study used one group pre-test - post-test design. The researcher made direct observations of a group of subjects with two conditions that were carried out without a comparison group so that each subject was a control class over itself.

Table 1. Research design

\begin{tabular}{ccc}
\hline Pre-test & Treatment $(\mathrm{X})$ & Post-test \\
\hline $\mathrm{O}_{1}$ & $\mathrm{Xn}$ & $\mathrm{O}_{2}$ \\
\hline Description: & $\mathrm{O}_{1}=$ Pre-test \\
& \\
& $\mathrm{X}_{\mathrm{n}}=$ Treatment & \\
$\mathrm{O}_{2}=$ Post-test &
\end{tabular}

The sample in this research were 56 undergraduate students of elementary school teacher programs at the Universitas Terbuka (UT) who were taking science learning courses in elementary school. Respondents conducted a tutorial in the Jember Regional Office area as a representation of the East Java region. Students who filled out responses are participants who carry out tutorial models of blended learning science learning courses in elementary school.

This research applies the results of the development of a model that is blended learning of new generation science learning materials. The materials include topic 1 (Learning Theory), topic 2 (Strategy and Media), and topic 3 (Process and Results Evaluation). The design of the mixed model used in the science learning tutorial in elementary school combines online, offline, and print learning materials and resources in the tutorial process. This study applies an inquiry learning procedure. The tutorial process goes through stages (1) Orientation; (2) Formulate the problem; (3) Formulate a hypothesis; (4) Collecting data/information; Testing hypotheses; (6) Formulate conclusions.

The research data were collected through tests, observation, and response questionnaires. Observation of student activities is carried out during the tutorial process to measure process skills, i.e. (1) observation, (2) classification, (3) interpretation, (4) prediction, (5) hypothesis, (6) controlling variables, (7) planning and conducting research, (8) inference, (9) application, and (10) communication. The effectiveness of the blended learning of the new generation of science learning materials is supported by learning outcomes that are evaluated after the implementation of the model. Student learning outcomes after following the tutorial are known with Bloom's revised taxonomy consisting of analysing, evaluating, and creating [26]. After the tutorial ends, students fill in the responses using detailed questionnaires whose contents have levels. The Likert scale is used to describe student responses to the implementation of learning.

The percentage analysis of $\mathrm{N}$-gain score ranges for description as follows: (1) high: the percentage is $>$ $66.67 \%$; (2) moderate: the percentage is $<66.67 \%$ and $\geq 33.33 \%$; and (3) low: the percentage is $<33.33 \%$. Student learning outcomes improvement can be said to improve according to the $\mathrm{N}$-gain formula (post-test score - pre-test score) / (100 - pretest score) [27]. Therefore, set of the N-gain criteria is as follows: (1) if $\mathrm{N}$-gain .7 (high), (2) if $\mathrm{N}$-gain is $>$ .3 and $<.7$ (moderate), and (3) if $\mathrm{N}$-gain is $\leq .3$ (low). The response of the elementary school teachers towards the questions of the questionnaire is divided into five categories: $5=$ very satisfactory / VS; $4=$ satisfactory / S; $3=$ quite satisfactory / QS; $2=$ less satisfactory $/$ LS; $1=$ very unsatisfactory $/$ VUS.

\section{Results and Discussion}

This research produces data on the results of the implementation of the blended learning of new generation science learning materials. Data consists 
of science process skills, learning outcomes, and student responses to tutorials. In this research, science process skills, when following a blended learning tutorial, were obtained by asking several questions covering the effectiveness of undergraduate students of elementary school teacher programs before and after the tutorial process and the category of science process skills through a tutorial using blended learning. Process skills in learning science in elementary schools can be seen in Figure 1., Table 2., Table 3., and Table 4.

Figure 1. shows the percentage of $\mathrm{N}$-gain criteria for student learning outcomes components in 2 testing groups using the tutorial model of blended learning new generation science learning materials. The rate of N-gain teachers who get high criteria in the analysis component reaches the most significant number compared to other parts.

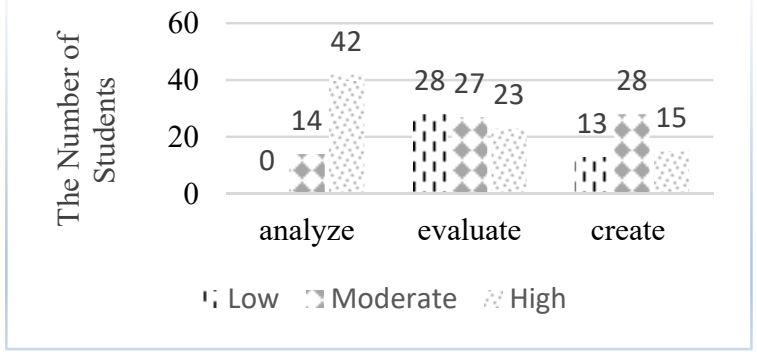

Figure 1. Percentage of $N$-gain criteria for student learning outcomes in 2 testing groups

Figure 1. shows the results of the assessment based on student frequency.

The highest rate is achieved in analytical skills. Most students can analyse learning theories to overcome the problems of science learning in natural science class. For example, the results of the student analysis on Piaget's approach that has a vital role in improving the understanding of elementary students.
The latter generally have the wrong answer when answering science knowledge. Piaget's theory of schemata explains that children's mental structures and ways of thinking can be developed with two bits of knowledge, namely, the knowledge of objects and events around them and the knowledge of how to do things. Students are quite capable of evaluating science teaching models and methods in elementary schools. They are quite capable of assessing science teaching models and methods in primary schools. For example, students can evaluate the teaching process used to convey material about floating and sinking objects. They use the inquiry learning model and do a demonstration in the form of a picture of events. Teachers can use the ICT by showing video events to students. Most students can create science teaching and learn in elementary schools quite well. For example, students can compile learning plans comprehensively by applying appropriate models and methods. The teacher conducts an assessment aimed at determining the level of student learning achievement as well as feedback for improving the learning process carried out using relevant instruments [28]. The assessment process when applying blended learning requires the ability to combine various types of assessments, for example, tests, non-tests, and authentic tests [29]. Designers should consider mixed assessments of online and offline processes [30]. They are thus providing the convenience and flexibility of participants learning to follow or make the assessment.

Table 2. shows the percentage of science process skills criteria for undergraduate students of elementary school teacher programs in the two testing groups. The rate of science process skills that have high criteria in components A1, A2, and A9 reaches a large number compared to other components.

Table 2. Percentage of students' scientific process skills criteria in the 2 testing groups

\begin{tabular}{|c|c|c|c|c|c|c|c|c|c|c|c|}
\hline & Component & A1 & $\mathrm{A} 2$ & A3 & A4 & A5 & A6 & A7 & A8 & A9 & A10 \\
\hline \multirow{3}{*}{1} & High & 91.07 & 91.07 & - & - & - & - & - & - & 94.64 & - \\
\hline & Moderate & - & - & 60.71 & 58.93 & 62.5 & 64.29 & 60.71 & 60.71 & - & 50 \\
\hline & Low & - & - & - & - & - & - & - & - & - & - \\
\hline \multirow{3}{*}{2} & High & 94.64 & 92.86 & - & 82.14 & - & - & - & 85.71 & 96.43 & - \\
\hline & Moderate & - & - & 66.07 & - & 64.29 & 66.07 & 62.5 & - & - & 60.71 \\
\hline & Low & - & - & - & - & - & - & - & - & - & - \\
\hline \multirow{3}{*}{3} & High & 96.43 & 96.43 & 69.64 & 87.5 & - & - & 73.21 & 85.71 & 98.21 & 67.86 \\
\hline & Moderate & - & - & - & - & 64.29 & 64.29 & - & - & - & - \\
\hline & Low & - & - & - & - & - & - & - & - & - & - \\
\hline
\end{tabular}

Description: (A1) observation, (A2) classification, (A3) interpretation, (A4) prediction, (A5) hypothesis, (A6) controlling variables, (A7) planning and conducting research, (A8) inference, (A9) application, and (A10) communication 
Table 2. shows that the implementation of the blended learning of the new generation of science learning materials is sufficient for training the science process skills of students. Most indicators of science process skills have been achieved in either category. However, several indicators state the medium category. Progress is happening in the world of communication, and information technology raises new opportunities and challenges in the world of education. Unique opportunities that arise include broader access to more precious multimedia content and the development of new learning methods that are no longer limited by time and space [31]. On the other hand, advances in technology with a variety of digital innovations that continue to develop also present new challenges for education providers to continue to adjust the education infrastructure with these new technologies. Collaboration is an activity that combines both educators and students, both of which can cross schools/campuses. Thus, the designer of blended learning must be in the form of collaboration, both between peers or collaboration between students and educators through possible communication tools such as chatrooms, discussion forums, e-mails, websites/weblogs, and mobile phones [32]. Of course, collaboration is directed to the construction of knowledge and skills through social processes or social interactions with others, which can be for the deepening of the material, problem-solving, and project-based learning. Performance support materials, if we want to combine face-to-face learning in class and virtual face-to-face learning, pay attention to the resources to support it whether or not it is available [33].

Table 3. shows the average initial learning outcomes of each student obtained after implementing various teaching methods as routine learning in the 2 testing groups. Student's early learning results show that they do not meet standards well. The average results of the implementation of the blended learning new generation science learning materials in Table 3. show an increase.

Table 3. Average pre-test, post-test, and n-gain components of student learning outcomes in the 2 test groups

\begin{tabular}{ccccc}
\hline Component & Pre-test average score & Post-test average score & N-gain & N-gain Level \\
\hline Analyse & 71.25 & 96.70 & 0.8 & High \\
\hline Evaluate & 62.50 & 88.39 & 0.6 & Moderate \\
\hline Create & 57.77 & 82.05 & 0.5 & Moderate \\
\hline
\end{tabular}

Table 3. shows the average initial learning outcomes of each student obtained after a tutorial with tutors who implemented various teaching strategies as routines in the two testing classes. Student learning outcomes indicate the level of Ngain is dominated by the medium level in the three components of learning outcomes. A student will take learning activities seriously if he is interested in these activities, and is aware of the teaching material being studied that can help achieve the expectations he wants [34]. Relevant support also shows that blended learning is effective in improving student learning outcomes [35]. The learning system at the UT requires students to have quite high learning independence. Students are required to research lecture materials independently as well as other learning services such as face-to-face tutorial services. The ability of students to use the media or learning resources properly, correctly, and not encounter many difficulties will determine the success of their learning [36]. In contrast, some students are not successful in taking the exam as a result of their lack of readiness in learning and their lack of ability to utilize available learning resources.
In the distance learning system as implemented at the UT, the perseverance in attending lectures can be shifted into determination to use the learning resources available at the UT and various relevant learning resources available on the Internet, as well as perseverance in fulfilling and doing individual tasks that are given. For this reason, students must organize and use a learning environment that genuinely supports their learning activities. With the support of an adequate learning environment, interest, passion, joy, and smooth learning will be guaranteed, and not much time is wasted so that learning activities will be active [37]. By the form of the distance learning system, students conduct learning activities by dealing directly with the media; in this case, the leading learning media are printed media in the form of modules. Besides using printed media modules, other media are also used, such as audio cassette media and other supporting books.

The results of students' responses to the process of the blended learning of the new generation of science learning materials are shown in Table 4. 
Table 4. Student responses to the implementation of the blended learning

\begin{tabular}{|c|c|c|c|c|}
\hline \multirow{2}{*}{ Criteria } & \multicolumn{4}{|c|}{ Categories $(\%)$} \\
\hline & VS & $\mathrm{S}$ & QS & LS \\
\hline \multicolumn{5}{|c|}{ Tutorial activities can help students explore science process skills } \\
\hline a. Observation & 57.14 & 30.36 & 12.5 & 0 \\
\hline b. Classification & 32.14 & 53.57 & 14.29 & 0 \\
\hline c. Interpretation & 1.79 & 62.5 & 33.93 & 1.79 \\
\hline d. Prediction & 0 & 37.5 & 37.5 & 17.86 \\
\hline e. Hypothesis & 21.43 & 78.57 & 0 & 0 \\
\hline f. Control variables & 21.43 & 71.43 & 7.14 & 0 \\
\hline g. Plan and carry out research & 5.36 & 46.43 & 42.86 & 5.36 \\
\hline h. Inference & 1.79 & 58.93 & 35.71 & 3.57 \\
\hline i. Application & 26.79 & 55.36 & 17.86 & 0 \\
\hline j. Communication & 16.07 & 75 & 8.93 & 0 \\
\hline \multicolumn{5}{|l|}{ The effectiveness of the tutorial using blended learning } \\
\hline a. Learning using blended learning strategies is more innovative and fun. & 19.64 & 57.14 & 23.21 & 0 \\
\hline b. Blended learning is a good learning design and helps to learn. & 16.07 & 69.64 & 14.29 & 0 \\
\hline $\begin{array}{l}\text { c.The material in blended learning that contains visualization/animation or } \\
\text { simulation really helped me in understanding the material. }\end{array}$ & 8.93 & 67.86 & 23.21 & 0 \\
\hline $\begin{array}{l}\text { d. Each topic has included a schedule of online and face-to-face activities in } \\
\text { class. }\end{array}$ & 14.29 & 67.86 & 17.86 & 0 \\
\hline $\begin{array}{l}\text { e. I feel clearer if the learning indicators are explained early, the material is } \\
\text { face-to-face, then continued with online activities. }\end{array}$ & 5.36 & 46.43 & 39.29 & 8.93 \\
\hline \multicolumn{5}{|c|}{ Suggestion applies blended learning new generation science learning materials } \\
\hline $\begin{array}{l}\text { a. I am happy if the science learning tutorial in elementary schools utilizes } \\
\text { the ICT. }\end{array}$ & 3.57 & 78.57 & 17.86 & 0 \\
\hline $\begin{array}{l}\text { b. I want to follow a science learning tutorial in elementary school that } \\
\text { combines online and face-to-face. }\end{array}$ & 14.29 & 60.71 & 25 & 0 \\
\hline $\begin{array}{l}\text { c. Blended learning new generation science learning materials are relevant to } \\
\text { present and future lives. }\end{array}$ & 1.79 & 69.64 & 28.57 & 0 \\
\hline $\begin{array}{l}\text { d. Blended learning materials for the new generation of science have utilized } \\
\text { the ICT so that they have a high potential to facilitate learning. }\end{array}$ & 1.79 & 51.79 & 42.86 & 3.57 \\
\hline $\begin{array}{l}\text { e. Blended learning - practical learning materials for the new generation } \\
\text { Practically applied using cell phones and laptops, making it suitable for } \\
\text { studying students who have additional work besides teaching. }\end{array}$ & 7.14 & 73.21 & 19.64 & 0 \\
\hline
\end{tabular}

Description: VS (very satisfactory), S(satisfactory), QS (quite satisfactory), LS (less satisfactory), and VUS (very unsatisfactory)

Students demonstrate a positive response to the tutorial they have done. Student responses are based on the science process skills they have experienced, the learning outcomes, and the blended learning processes that have been passed, and the ICT-based tutorials in general. Table 4. concludes that the response predominantly stated in the tutorial was using blended learning of the new generation of science learning materials for elementary school teacher programs helping students practice science process skills. Besides, recommendations for applying this model in science learning tutorials in elementary schools are also supported by students. The success of online learning also requires students who are self-directed, self-regulated, self-disciplined, and comfortable with written communication to have information-sharing characters and have technical skills [38]. Blended learning is a combination of learning delivery strategies that take advantage of online and face-to-face learning. Although blended learning offers great hope for improving the effectiveness of education, this delivery strategy must be supported by student characteristics. High interest in the application of blended learning is a definite starting point for the implementation of blended learning. A positive attitude and perception towards learning is the first focus of the five dimensions of active learning. Without positive attitudes and perceptions of education, students will not make optimal efforts in learning [39]. Distance learning is the training given to participants or students who do not gather together in one place regularly to receive lessons directly from the instructor [40]. Specific detailed materials and instructions are sent or made available to participants who then carry out tasks to be evaluated by the instructor [41]. In reality, the instructor and the participant can be separated not only geographically but also in time. Distance learning allows participants to take classes anytime and anywhere. Distance learning will enable them to adapt their education and training to other responsibilities and commitments, such as family and work. It also provides an opportunity for participants who may not 
be able to research because of limited time, distance, or funds to participate. Distance learning can be beneficial, especially for participants who are more mature and have strong motivation to pursue success, and are happy to be entrusted with the process of learning independently [42].

\section{Conclusion}

The research shows that the blended learning of the new generation of science learning materials is useful to improve the science process skills of undergraduate students of elementary school teacher programs at the Universitas Terbuka. Also, the effectiveness of this model is supported by student learning outcomes to improve mastery of concepts related to learning theory, strategies, and evaluation of science learning in elementary schools. The effectiveness of the implementation of blended learning shows that this model is easily applied in the tutorial. Student responses also showed student acceptance in following the blended learning tutorial. Students have positively perceived the blended learning of the new generation of science learning materials, and this perception needs to be maintained through good design. Although some students say blended learning has the potential to be confusing, online discussions are believed to help them learn. Students have very high confidence in blended learning. This belief will help them determine if blended learning is well designed. This indicates that internet-assisted education that they have experienced is felt to be unsatisfactory, but they still have high expectations that blended learning will be sufficient.

\section{Implications}

From the findings, discussions, and conclusions of this research, the following things can be recommended. The blended learning of the new generation of science learning materials is a tutorial model for students that effectively improve science process skills. The implementation of the model needs to be designed by both the tutor and the students when viewed from the current state of facilities and infrastructure in Indonesia. Besides, this research has a weakness that is not yet able to be carried out on a broader scale on the territory of Indonesia, which is an archipelago. The limitation happens because of the limited time, energy, and available funds.

\section{Acknowledgements}

The authors would like to appreciate the Ministry of Finance of the Republic of Indonesia and Universitas Terbuka Research Center for the funds to complete this research. Furthermore, the UT Regional Office area of Jember - East of Java, Indonesia for the support in the implementation of the blended learning in the context of distance learning. At last, the authors also thank validators who made this research can be carried out properly.

\section{References}

[1]. Ramey-Gassert, L. (1997). Learning science beyond the classroom. The elementary school journal, 97(4), 433-450.

[2]. Perez, T., Wormington, S. V., Barger, M. M., Schwartz-Bloom, R. D., Lee, Y. K., \& LinnenbrinkGarcia, L. (2019). Science expectancy, value, and cost profiles and their proximal and distal relations to undergraduate science, technology, engineering, and math persistence. Science education, 103(2), 264-286.

[3]. Bowser, A., Davis, K., Singleton, J., \& Small, T. (2017). Professional learning: A collaborative model for online teaching and development. SRATE Journal, 26(1), 1-8.

[4]. Jatmiko, B., Prahani, B. K., Munasir, S., Wicaksono, I., Erlina, N., \& Pandiangan, P. (2018). The comparison of OR-IPA teaching model and problem based learning model effectiveness to improve critical thinking skills of pre-service physics teachers. Journal of Baltic Science Education, 17(2), 300 .

[5]. Evans, J. C., Yip, H., Chan, K., Armatas, C., \& Tse, A. (2020). Blended learning in higher education: professional development in a Hong Kong university. Higher Education Research \& Development, 39(4), 643-656.

[6]. Sukardjo, M., \& Salam, M. (2020). Effect of Concept Attainment Models and Self-Directed Learning (SDL) on Mathematics Learning Outcomes. International Journal of Instruction, 13(3), 275-292.

[7]. Bennett, J., Hanley, P., Abrahams, I., Elliott, L., \& Turkenburg-van Diepen, M. (2019). Mixed methods, mixed outcomes? Combining an RCT and case studies to research the impact of a training programme for primary school science teachers. International journal of science education, 41(4), 490-509.

[8]. Dangprasert, S. (2021). Effects on Using Tutoring Application in Integration with Self-Directed Learning to Improve Statistical Analysis Skills. TEM Journal, 10(1), 63-68.

[9]. Samputrii, S. (2020). Science Process Skills and Cognitive Learning Outcomes Through Discovery Learning Models. European Journal of Education Studies, 6(12), 182.

[10]. Ergül, R., Şımşeklı, Y., Çaliş, S., Özdılek, Z., Göçmençeleb1, Ş., \& Şanli, M. (2011). The Effects of Inquiry-Based Science Teaching on Elementary School Students'science Process Skills and Science Attitudes. Bulgarian Journal of Science \& Education Policy, 5(1). 
[11]. Erlina, N., Susantini, E., Wasis, W., \& Pandiangan, P. (2018). The effectiveness of evidence-based reasoning in inquiry-based physics teaching to increase students' scientific reasoning. Journal of Baltic Science Education, 17(6), 972.

[12]. Meissner, D. (2019). Public-private partnership models for science, technology, and innovation cooperation. Journal of the Knowledge Economy, 10(4), 1341-1361.

[13]. Arianto, F., Susarno, L. H., Dewi, U., \& Safitri, A. F. (2020). Model Penerimaan dan Pemanfaatan Teknologi: E-learning di Perguruan Tinggi. Kwangsan, 8(1), 332459.

[14]. Budiastra, A. K., Erlina, N., \& Wicaksono, I. (2019). Video-based interaction through teacher working group forum to increase elementary school teachers' professionalism. New Educational Review,57(3), 187-199.

[15]. Adeleke, G. A., \& Jegede, P. O. (2020). Comparative effects of ICT-Integrated Learning Strategies on spatial reasoning skills among Nigerian lower primary school pupils. European Journal of Education, 3(1), 31-35.

[16]. Han, F., \& Ellis, R. A. (2020). Initial development and validation of the perceptions of the blended learning environment questionnaire. Journal of Psychoeducational Assessment, 38(2), 168-181.

[17]. Lim, C., Ab Jalil, H., Ma'rof, A., \& Saad, W. (2020). Peer Learning, Self-Regulated Learning and Academic Achievement in Blended Learning Courses: A Structural Equation Modeling Approach. International Journal of Emerging Technologies in Learning (IJET), 15(3), 110-125.

[18]. Carman, J. M. (2005). Blended Learning Design: Five Key Ingredients. Agilant Learning.

[19]. Han, F., \& Ellis, R. A. (2019). Identifying consistent patterns of quality learning discussions in blended learning. The Internet and Higher Education, 40, 1219.

[20]. Thompson, K., Jowallah, R., \& Cavanagh, T. B. (2019). "Solve the Big Problems": Leading Through Strategic Innovation in Blended Teaching and Learning. In Technology leadership for innovation in higher education (pp. 26-48). IGI Global.

[21]. Allen, I. E., Seaman, J., \& Garrett, R. (2007). Blending in: The extent and promise of blended education in the United States. Sloan Consortium. PO Box 1238, Newburyport, MA 01950.

[22]. Suparman, M. A., 2018. Materi pelatihan pengembangan bahan pembelajaran generasi baru Universitas Terbuka (BPGERU-UT) [Training materials for the development of new generation learning materials for the Universitas Terbuka (BPGERU-UT).]. Training materials. Jakarta: Universitas Terbuka.

[23]. Aripin, S., \& Hidayat, A., 2019. Discusion-making techniques in managing Universitas Terbuka Regional Offices in Indonesia. In: AAOU Annual conference, 288-291.
[24]. Youde, A. (2020). I don't need peer support: effective tutoring in blended learning environments for part-time, adult learners. Higher Education Research \& Development, 39(5), 1040-1054.

[25]. Zhang, W., \& Zhu, C. (2020). Blended learning as a good practice in ESL courses compared to F2F learning and online learning. International Journal of Mobile and Blended Learning (IJMBL), 12(1), 64-81.

[26]. Wicaksono, I., \& Wasis, M. (2017). The effectiveness of virtual science teaching model (VSTM) to improve student's scientific creativity and concept mastery on senior high school physics subject. Journal of Baltic Science Education, 16(4), 549.

[27]. Hake, R. R. (1998). Interactive-engagement versus traditional methods: A six-thousand-student survey of mechanics test data for introductory physics courses. American journal of Physics, 66(1), 64-74.

[28]. Arumugham, K. S. (2019). Teachers' Understanding towards Portfolio Assessment: A Case Study among Malaysian Primary School Teachers. Problems of Education in the 21st Century, 77(6), 695-704.

[29]. Fishman, B., Konstantopoulos, S., Kubitskey, B. W., Vath, R., Park, G., Johnson, H., \& Edelson, D. C. (2013). Comparing the impact of online and face-toface professional development in the context of curriculum implementation. Journal of teacher education, 64(5), 426-438.

[30]. Asarta, C. J., \& Schmidt, J. R. (2020). The effects of online and blended experience on outcomes in a blended learning environment. The Internet and Higher Education, 44, 100708.

[31]. Susilawati, S., Doyan, A., Artayasa, P., Soeprianto, H., Harjono, A., \& Kartini, K. (2020, March). Effectiveness of Scientific Learning Guided Inquiry Devices Based on Real Media to Improve Understand Concept and Skills Process of Science Students. In International Conference on Elementary Education (Vol. 2, No. 1, pp. 517-524).

[32]. Mofield, E. L. (2020). Benefits and Barriers to Collaboration and Co-Teaching: Examining Perspectives of Gifted Education Teachers and General Education Teachers. Gifted Child Today, 43(1), 20-33.

[33]. Ranieri, M., Giampaolo, M., \& Bruni, I. (2019). Exploring educators' professional learning ecologies in a blended learning environment. British Journal of Educational Technology, 50(4), 1673-1686.

[34]. Maksum, A., \& Khory, F. D. (2020). Effect of Learning Climate, Thinking Pattern, and Curiosity on Academic Performance in Higher Education. Problems of Education in the 21st Century, 78(1), 102-113.

[35]. Utomo, S. W., \& Wihartanti, L. V. (2019). Penerapan Strategi Blended Learning untuk Meningkatkan Kemampuan Berpikir Kritis Mahasiswa pada Era Revolusi Industri 4.0. Jurnal Teknologi Pendidikan, 7(1), 30-44.

[36]. López-Pérez, M. V., Pérez-López, M. C., \& Rodríguez-Ariza, L. (2011). Blended learning in higher education: Students' perceptions and their relation to outcomes. Computers \& education, 56(3), 818-826. 
[37]. Ainin, M., Ahsanuddin, M., Asrori, I., \& Ibrahim, F. M. A. (2019). Designing Online-Based Independent Learning Network for the Development of Arabic Language Research Methodology (ALRM) at State University of Malang, Indonesia. Journal of Education and e-Learning Research, 7(1), 7-14.

[38]. Owston, R., York, D. N., \& Malhotra, T. (2019). Blended learning in large enrolment courses: Student perceptions across four different instructional models. Australasian Journal of Educational Technology, 35(5), 29-45.

[39]. Marzano, R. J. (1993). How classroom teachers approach the teaching of thinking. Theory into practice, 32(3), 154-160.

[40]. Gunawardena, C. N., \& McIsaac, M. S. (2013). Distance education. In Handbook of research on educational communications and technology (pp. 361401). Routledge.
[41]. Ali, A., Mushtaq, R., \& Wani, S. (2019). Virtual learning environment: a case study of edX MOOC platform. J. Adv. Libr. Sci, 6(1), 118-122.

[42]. Simonson, M., Zvacek, S. M., \& Smaldino, S. (2019). Teaching and Learning at a Distance: Foundations of Distance Education 7th Edition.

[43]. Bruggeman, B., Tondeur, J., Struyven, K., Pynoo, B., Garone, A., \& Vanslambrouck, S. (2021). Experts speaking: Crucial teacher attributes for implementing blended learning in higher education. The Internet and Higher Education, 48, 100772.

[44]. Rafiola, R., Setyosari, P., Radjah, C., \& Ramli, M. (2020). The Effect of Learning Motivation, SelfEfficacy, and Blended Learning on Students' Achievement in The Industrial Revolution 4.0. International Journal of Emerging Technologies in Learning (iJET), 15(8), 71-82.

[45]. Rasheed, R. A., Kamsin, A., \& Abdullah, N. A. (2020). Challenges in the online component of blended learning: A systematic review. Computers \& Education, 144, 103701. 